\title{
Intestinal Absorption of Sucrose in Man: The Site of Hydrolysis and Absorption *
}

\author{
Gary M. Gray $\dagger$ and Franz J. Ingelfinger \\ (From the Evans Memorial Department of Clinical Research, Massachusetts Memorial Hos- \\ pitals, and the Department of Medicine, Boston University School of Medicine, \\ Boston University Medical Center, Boston, Mass.)
}

Sucrose, unlike the other common disaccharides, maltose and lactose, has been reported to be absorbed poorly from jejunum in man. Using a single-lumen tube technique and giving a carbohydrate-protein-fat meal with a single disaccharide as the source of carbohydrate, Dahlqvist and Borgström (1) reported efficient absorption of lactose and maltose from human jejunum but minimal absorption of sucrose. They assumed that sucrose must have been absorbed in lower jejunum and ileum, but no ileal studies were performed. This apparent difference in the site of absorption of sucrose as compared to maltose and lactose has been quoted as fact $(2,3)$, and, if true, might serve to distinguish jejunal and ileal malabsorptive disease in man on the basis of comparative blood sugar curves after ingestion of the different disaccharides.

Dahlqvist (4) subsequently reported data demonstrating maximal activity in human jejunum for the sucrose splitting enzyme, sucrase, but he did not relate this information to the site of hydrolysis and absorption of sucrose. In addition, recent extensive disaccharidase determinations on human intestinal mucosa by Auricchio and co-workers (5) have demonstrated activity of sucrase in jejunal and ileal mucosa to be similar, a finding that would not be expected if sucrose were hydrolyzed and absorbed principally in ileum.

* Submitted for publication August 25, 1964; accepted November 19, 1964.

Supported in part by U. S. Public Health Service research grants AM 03560-04 and 05 and by training grants T1 AM 5025-07 and 08 from the National Institute of Arthritis and Metabolic Diseases.

Presented in part at the Annual Meeting of the Gastroenterological Research Forum, Dallas, Texas, April 23, 1964.

$\dagger$ Address requests for reprints to: Captain Gary M. Gray, MC, U. S. Army Tropical Research Medical Laboratory, APO, New York 09851 (San Juan, P. R.).
The present studies were designed to examine further the absorption of sucrose in normal man.

\section{Methods}

Twenty-three normal young adults (21 males, 2 females) were studied on 50 occasions. A double-lumen polyvinyl tube with a small, terminal, mercury-filled balloon (6) was swallowed the evening before the study and allowed to move into the small intestine overnight. Subjects were permitted to have a supper containing clear liquids on the day before the study, but they ingested nothing but water for the 12-hour period before begining the experiment. One lumen of the tube was used to collect intestinal samples through an orifice placed just proximal to the terminal balloon. The other lumen, through which the test solution was infused, had its opening $30 \mathrm{~cm}$ proximal to the collecting orifice. Position of the tube was checked fluoroscopically before the study, and any coiling in the stomach was removed. When the collecting orifice was a distance of 60 to $100 \mathrm{~cm}$ from the incisor teeth, it was found fluoroscopically to be in the duodenum, when 100 to $170 \mathrm{~cm}$ in the jejunum, and when 170 to $260 \mathrm{~cm}$ in the ileum. At distances exceeding $260 \mathrm{~cm}$, the distal orifice of the tube was often found to be in the colon. These relationships are similar to those previously reported $(1,6-8)$.

The test solution contained sucrose ${ }^{1}$ at a concentration of $73 \mathrm{mM}$ ( $2.5 \%$ solution) or $146 \mathrm{mM}$ ( $5 \%$ solution) as well as sufficient sodium chloride to make the osmolality $290 \pm 10$. These concentrations of sucrose were selected because Dahlqvist and Borgström found disaccharide concentrations to be in this range in human intestinal contents after an oral meal (1). The solution was infused through the proximal lumen at $15 \mathrm{ml}$ per minute by a peristaltic pump, ${ }^{2}$ and two to four consecutive 20 -minute samples were collected by siphonage from the collecting orifice $30 \mathrm{~cm}$ distal to the point of infusion. Approximately $20 \%$ of the infused volume was collected by this technique. Polyethylene glycol 4000 (PEG) $0.5 \%$ was added to the infusate as the nonab-

$1 \alpha$-D-Glucopyranosyl $\beta$-D-fructofuranoside, analytical grade, Merck Co., Rahway, N. J. All sugars were found to have less than $0.5 \%$ impurity by paper chromatography.

2 Model 600-1200, Harvard Apparatus Co., Dover, Mass. 
sorbable, water-soluble marker, and measured by a modification of Hydén's method (9). After an initial 30-minute equilibration period, there was little variation in the concentration of PEG in siphoned samples from one collection period to the next (mean $\pm 5 \%$ ), and the values for disappearance of the test sugar were reproducible (mean $\pm 7 \%$ ). Samples were collected in vessels surrounded by crushed ice and either deproteinized and analyzed immediately or stored at $-15^{\circ} \mathrm{C}$. Specimens frozen for 2 to 3 months were found to contain the same amounts of sucrose and its monosaccharide products as were present immediately after collection, and only minimal variations were noted even after freezing for 4 to 12 months. The infusate samples as well as those siphoned from the distal collecting site were deproteinized by $\mathrm{Ba}(\mathrm{OH})_{2}$ and $\mathrm{ZnSO}_{4}(10)$ and then filtered through no. 42 Whatman paper. The filtrate was analyzed for sucrose, its monosaccharide products, and PEG.

Sucrose determination. Sucrose was analyzed by a twostep reaction: $a$ ) hydrolysis of $1 \mathrm{ml}$ of deproteinized filtrate (containing up to $3 \mathrm{mg}$ of sucrose) by incubation for 1 hour at $37^{\circ} \mathrm{C}$ with $1 \mathrm{ml}$ of buffered yeast invertase solution (1) $\left(20 \mathrm{mg}\right.$ invertase $^{3}$ in $100 \mathrm{ml}$ of $0.1 \mathrm{M}$ sodium acetate adjusted to $\mathrm{pH} 4.5$ ) ; and $b$ ) assay of the glucose produced from the hydrolysis reaction by a modification of Huggett and Nixon's (11) glucose oxidase (G.O.) reagent $[25 \mathrm{mg}$ glucose oxidase, $43 \mathrm{mg}$ horseradish peroxidase, ${ }^{5} 0.5 \mathrm{ml}$ of $1 \%$ o-dianisidine in $95 \%$ ethanol, $100 \mathrm{ml} 0.5 \mathrm{M}$ Tris buffer (12) or $0.100 \mathrm{M}$ Tris$0.005 \mathrm{M}$ phosphate buffer (13) at $\mathrm{pH} 7.0]$. Any free glucose present in the original sample before the hydrolysis step was subtracted from total glucose found after hydrolysis. No filtering of the G.O. reagent was required, and it was stable for several days under refrigeration at $10^{\circ} \mathrm{C}$.

To $1 \mathrm{ml}$ of the hydrolyzed solution, diluted as necessary, $2.5 \mathrm{ml}$ of the G.O. reagent was added; incubation was carried out for 1 hour at $37^{\circ} \mathrm{C}$, and the color intensity was read at $420 \mathrm{~m} \mu$ in a spectrophotometer. Sucrose and D-glucose ${ }^{6}$ standard solutions, as well as appropriate reagent and invertase blanks, were handled identically to samples. A linear relationship of optical density to concentration prevailed from 0 to $75 \mu \mathrm{g}$ of glucose in the reaction mixture. Assay of hydrolyzed sucrose solutions for total glucose plus fructose by the hexokinase reagent (described below) showed that equal amounts of glucose and fructose were released when sucrose was hydrolyzed, thereby demonstrating that measurement of the glucose hydrolysis product is a valid means of determining sucrose. Sucrose or glucose or both added to small intestinal contents individually or in combination to yield 1 to $150 \mathrm{mM}$ concentrations could be recovered $100 \pm 5 \%$ by the method. The Tris in the buffer completely inhibited activity of contaminating in-

\footnotetext{
3 Analytical grade, Nutritional Biochemicals Corp. Cleveland, Ohio.

4 Purified Type II, Sigma Chemical Co., St. Louis, Mo.

5 Nutritional Biochemicals Corp., Cleveland, Ohio.

6 Analytical grade, Merck Co., Rahway, N. J.
}

vertase in the glucose oxidase so that it was possible to accurately assay $5 \mu \mathrm{g}$ of glucose even when $2,500 \mu \mathrm{g}$ of sucrose was present in the reaction mixture. Sensitivity of the method was found to be the same with the Tris buffered reagent as with the more commonly used phosphate buffer (11).

Glucose-fructose determination. Considerable quantities of glucose and fructose, the monosaccharide hydrolysis products of sucrose, were found in the collected intestinal samples. Total glucose plus fructose 7 was specifically assayed by a modification of Schmidt's (14) hexokinase-phosphohexose isomerase-glucose-6-phosphate dehydrogenase system. The hexokinase reagent consisted of $50 \mathrm{ml}$ of $.05 \mathrm{M}$ triethanolamine buffer at $\mathrm{pH} 7.6$ (15), $2 \mathrm{ml}$ of $100 \mathrm{mM} \mathrm{ATP,8} 2 \mathrm{ml}$ of $100 \mathrm{mM} \mathrm{MgCl}_{2}$, 16 enzyme $U$ of glucose-6-phosphate dehydrogenase, 98 enzyme $U$ of hexokinase, ${ }^{9}$ and 8 enzyme $U$ of phosphohexose isomerase. ${ }^{9}$ To $0.5 \mathrm{ml}$ of the deproteinized filtrate, suitably diluted, $2.5 \mathrm{ml}$ hexokinase reagent was added. One-tenth $\mathrm{ml}(0.4 \mathrm{mg})$ of TPN was added to start the reaction. The reaction mixture was incubated at $30^{\circ} \mathrm{C}$ for 1 hour, and the amount of TPNH produced was determined spectrophotometrically at $340 \mathrm{~m} \mu$. Deproteinized samples plus reagent were found to read the same as water plus reagent; hence it was not necessary to obtain a control spectrophotometric reading before adding TPN. However, a blank containing water, reagent, and TPN was used since the TPN itself did result in some spectrophotometric reading. Since deproteinized intestinal samples did not contain detectable amounts of intermediate reaction products (glucose-6-phosphate, fructose-6-phosphate), it was not necessary to add individual enzymes sequentially; therefore all enzymes were included in the reagent. Zero to $40 \mu \mathrm{g}$ of total hexose (glucose or fructose or both) in the reaction mixture resulted in a linear relationship of optical density to concentration. Optical density readings were stable for at least 2 hours after incubation, and sucrose in samples did not interfere with the reaction.

Sucrase assay. All samples collected during the studies were assayed by measuring the glucose released (G.O. method above) from incubation of equal volumes of collected intestinal sample and $0.056 \mathrm{M}$ sucrose substrate according to Dahlquist $(1,4)$ except for the following modifications: $a$ ) a buffer $\mathrm{pH}$ of 5.8 was used instead of 6.0, since Auricchio and co-workers (5) have shown this to be the $\mathrm{pH}$ optimum for human disaccharidases; $b$ ) the control reaction at time zero and the incubated reaction at 1 hour were stopped with $\mathrm{Ba}(\mathrm{OH})_{2-}$ $\mathrm{ZnSO}_{4}$ deproteinization (10) rather than by boiling. Deproteinization was found to be as effective as boiling in destroying the sucrase activity present.

Calculations. Sucrose that disappears from the intestinal lumen might be absorbed intact or be hydrolyzed

\footnotetext{
' D-Fructose, Pfanstiehl Co., Waukegan, Ill.

8 Sigma Chemical Co., St. Louis, Mo.

${ }^{9}$ C. F. Boehringer and Sons, Mannheim, Germany (distributed by California Corporation for Biochemical Research, Los Angeles, Calif.)
} 
to its monosaccharide products, glucose and fructose. However, in man no appreciable amount of sucrose appears to be absorbed intact into the blood, for any sucrose that enters blood is excreted quantitatively in urine (16-19), but only trace amounts are found in urine of humans after a sucrose meal (20-23). Further, no sucrosuria was found in our subjects as measured by enzymatic assay or by paper chromatography $(20,21)$. Hence it may be assumed that whatever sucrose disappears is hydrolyzed before it enters the blood stream.

Not all of the products of sucrose hydrolysis were absorbed, however, in the test segment, since appreciable quantities of glucose and fructose were found within the lumen at the collecting orifice. Hence sucrose absorption was determined in terms of its monosaccharide products as follows: sucrose disappearance $=$ sucrose hydrolysis $=2\left[\mathrm{~S}_{1} \cdot \mathrm{V}-\mathrm{S}_{\mathrm{c}} \cdot \mathrm{V} \cdot\left(\mathrm{P}_{1} / \mathrm{P}_{\mathrm{c}}\right)\right]$; sucrose absorption $=2\left[\mathrm{~S}_{1} \cdot \mathrm{V}-\mathrm{S}_{\mathrm{c}} \cdot \mathrm{V} \cdot \mathrm{P}_{1} / \mathrm{P}_{\mathrm{c}}\right]-\left[\left(\mathrm{G}_{\mathrm{c}}+\mathrm{F}_{\mathrm{c}}\right) \mathrm{V} \cdot\left(\mathrm{P}_{\mathrm{l}} / \mathrm{P}_{\mathrm{c}}\right)\right]$. Hydrolysis and absorption are expressed as millimoles monosaccharide per hour, and symbols refer to millimolar concentrations as follows: $S_{1}=$ sucrose in infusion; $S_{c}=$ sucrose in collected samples; $\mathrm{V}=$ volume (liters infused in 1 hour ); $\mathrm{P}_{1}=\mathrm{PEG}$ in infusion; $\mathrm{P}_{\mathrm{c}}=\mathrm{PEG}$ in collected samples; $\mathrm{G}_{\mathrm{c}}=$ unabsorbed glucose in collected samples; $\mathrm{F}_{\mathrm{c}}=$ unabsorbed fructose in collected samples.

\section{Results}

Site of sucrose hydrolysis and absorption. Figure 1 demonstrates the results of paired infusion studies carried out in eight subjects who received $73 \mathrm{mM}$ sucrose and in eight different subjects who were given $146 \mathrm{mM}$ sucrose. Except for one subject in each group, absorption of sucrose was more rapid from jejunal than from ileal segments, the differences being statistically significant for both $73 \mathrm{mM}$ and $146 \mathrm{mM}$ concentrations (paired analysis $t$ test, $\mathrm{p}<0.001)$. Figure 2 represents the results of 36 studies in 23 subjects given $146 \mathrm{mM}$ sucrose. Included are the paired studies previ-

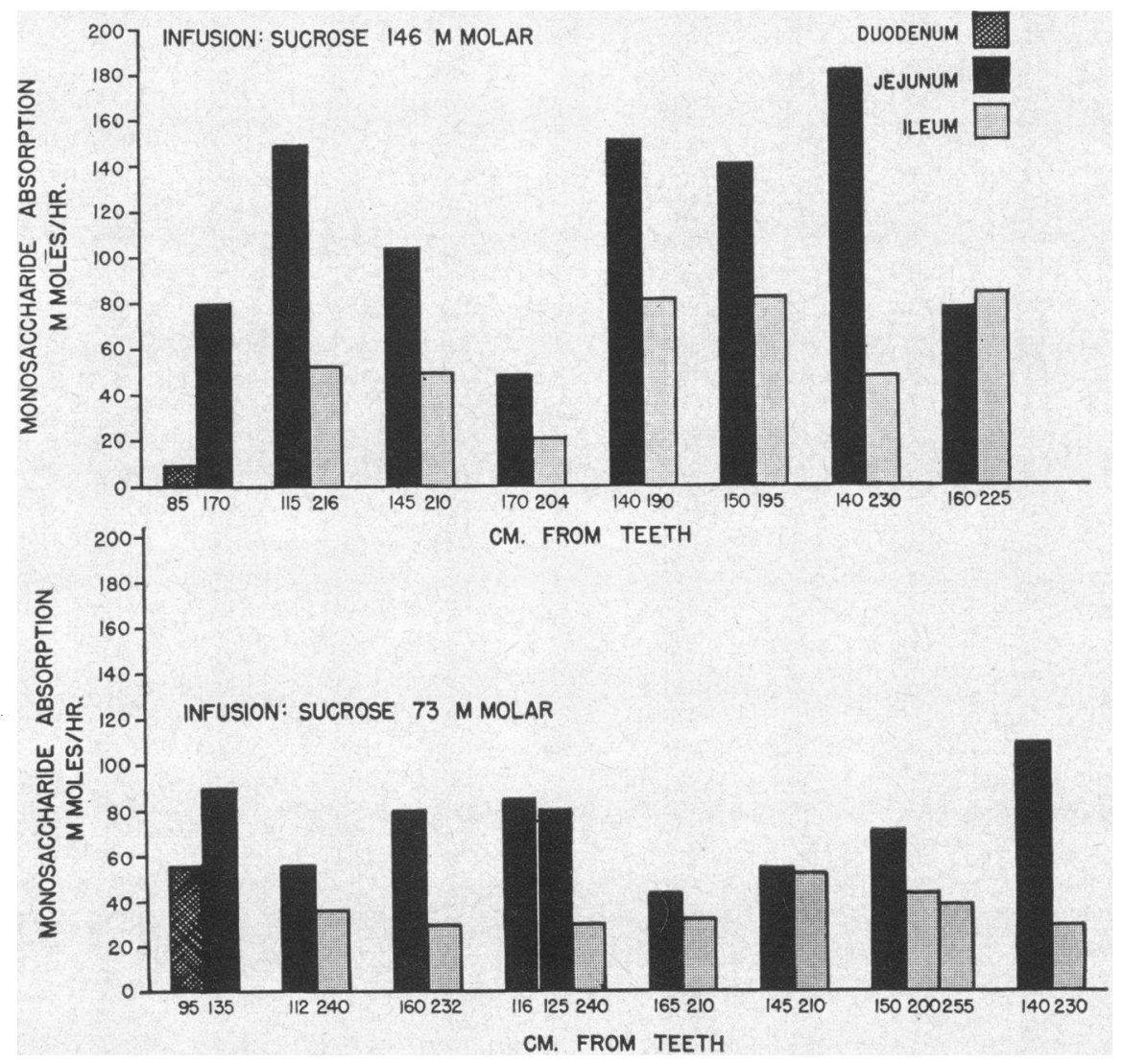

Fig. 1. Paired studies of Sucrose absorption in 30-CM intestinal segments AT VARIOUS INTESTINAL LEVEL. Each group of bars represents studies on one subject, and numbers under bars refer to intestinal level of collecting orifice. Sucrose absorption is expressed in terms of total monosaccharide absorption. Jejunal absorption rates are significantly greater than ileal $(p<0.001)$. 


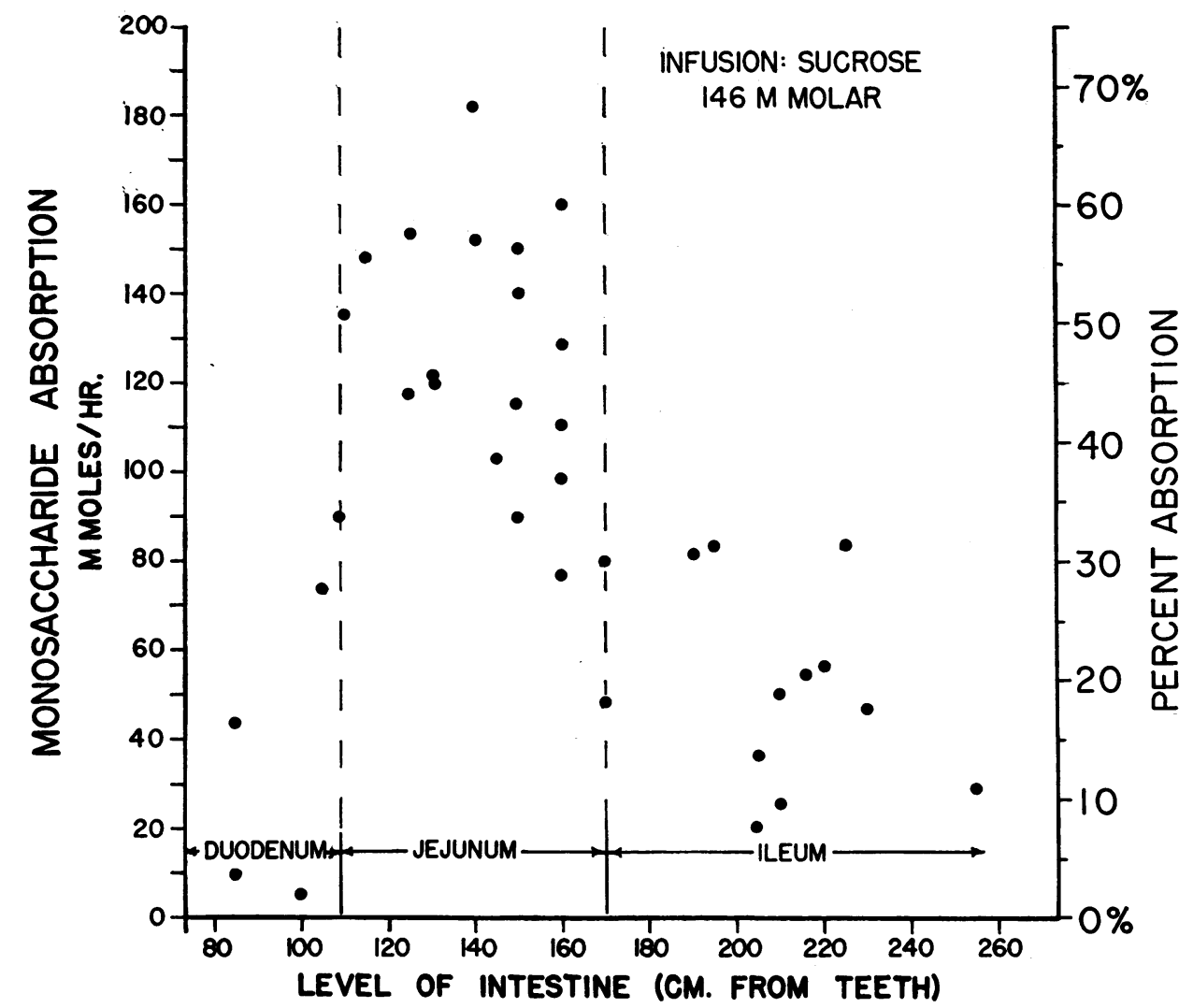

Fig. 2. Sucrose absorption from 30-CM intestinal segments. Absorption is expressed as in Figure 1. Included are the paired infusion studies shown in the upper half of Figure 1 as well as all other sucrose $146 \mathrm{mM}$ infusion studies. Jejunal absorption is significantly greater than ileal $(\mathrm{p}<0.001)$.

ously mentioned as well as all other studies with $146 \mathrm{mM}$ sucrose. Absorption was maximal in jejunum and considerably less in ileum $(p<0.001)$.

During the process of absorption of sucrose, its hydrolytic products glucose and fructose accumulated in the lumen in appreciable quantities. The amounts of total monosaccharide that appeared are shown in Figures 3 and 4 . The glucose and fructose that accumulated intraluminally presumably represented unabsorbed products of sucrose hydrolysis. That these monosaccharides did not come from a source other than sucrose is supported by the finding that intestinal contents of 15 fasting subjects, three of whom were given iv glucose to increase the gradient between blood and intestinal lumen, contained no detectable glucose or fructose.

Figure 3 relates monosaccharide accumulation to the level of intestine under study. Accumula- tion was slight in duodenum and considerably greater in jejunum and ileum; however, despite the greater sucrose absorption rates in jejunum, there was no difference in the amount of monosaccharide accumulating intraluminally in jejunal as compared to ileal segments. In addition, even though the intraluminal monosaccharides are produced from sucrose, the linear relationship between monosaccharide appearance and sucrose disappearance, i.e., sucrose hydrolysis, was of a low order $(r=0.51)$ (Figure 4). However, it is quite unlikely that this degree of correlation could have occurred by chance $(p<0.001)$.

Table I summarizes the results of all infusion studies. Comparison of the mean rates of hydrolysis and absorption demonstrates that hydrolysis exceeded absorption by a greater relative amount in ileum. This is expressed in the last two columns in Table I, where the fraction of hydrolyzed 
sucrose that was absorbed is compared with that which accumulated intraluminally. The fraction of hydrolyzed sucrose absorbed was significantly greater in jejunum than in ileum $(\mathrm{p}<0.01)$.

Intraluminal sucrase activity. Measured sucrase activity of intraluminal contents was quite low and could not account for the sucrose hydrolysis, as has been reported by others $(1,8)$. However, in addition, the sucrase activity of collected samples was not sufficient to explain the intraluminal monosaccharide accumulation (Figure 5). This suggests that these monosaccharides were released from sucrose split by mucosa-bound enzyme rather than from sucrose hydrolyzed by sucrase free in the intestinal contents.

It is of course possible that the in vitro sucrase assay of collected intestinal contents does not represent the true sucrase activity in vivo. If intraluminal sucrase were destroyed by a protease or by some other means after it had hydrolyzed its substrate, results of the sucrase assay would be falsely low. However, sucrase activity did not decrease appreciably when intestinal specimens were incubated at $37^{\circ}$ for 1 hour before assay (Table II). This suggests that there is negligible destruction of intraluminal sucrase in the few minutes required for the test solution to traverse the $30-\mathrm{cm}$ intestinal segment and therefore that the in vitro assay showing very low activity is a reasonable measure of intraluminal sucrase.

Oral meal studies. Since Dahlqvist and Borgström's finding of minimal absorption of sucrose in human jejunum was based on the use of a meal containing fat and protein as well as the disaccharide (1), four subjects were given the identical oral meal and samples collected from a single lumen tube placed at jejunal levels. As shown in Table III, 90 to $100 \%$ of the sucrose was absorbed by the time the meal reached mid- to low jejunal levels, and the small amount of sugar remaining intraluminally was almost completely in the form of monosaccharide products. Paper

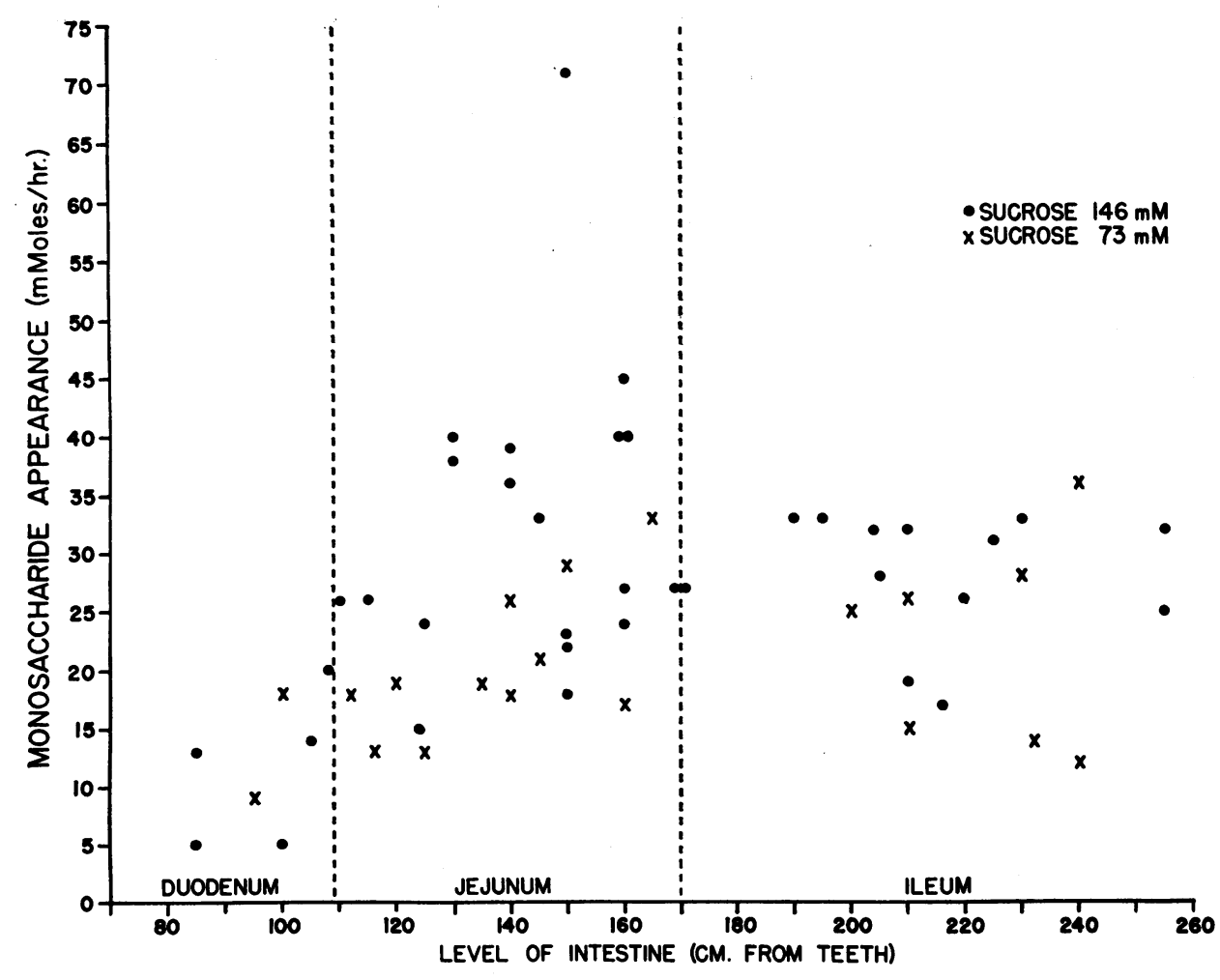

Fig. 3. INTRALUminal monosaccharide APPEARANCE at DIFFERENT levels of intestine DURING SUCROSE INFUSION STUDIES. Both $73 \mathrm{mM}$ and $146 \mathrm{mM}$ sucrose studies are included, since values for the two groups were not significantly different. Monosaccharide appearance indicates total glucose plus fructose accumulation found over the $30-\mathrm{cm}$ test segment. 


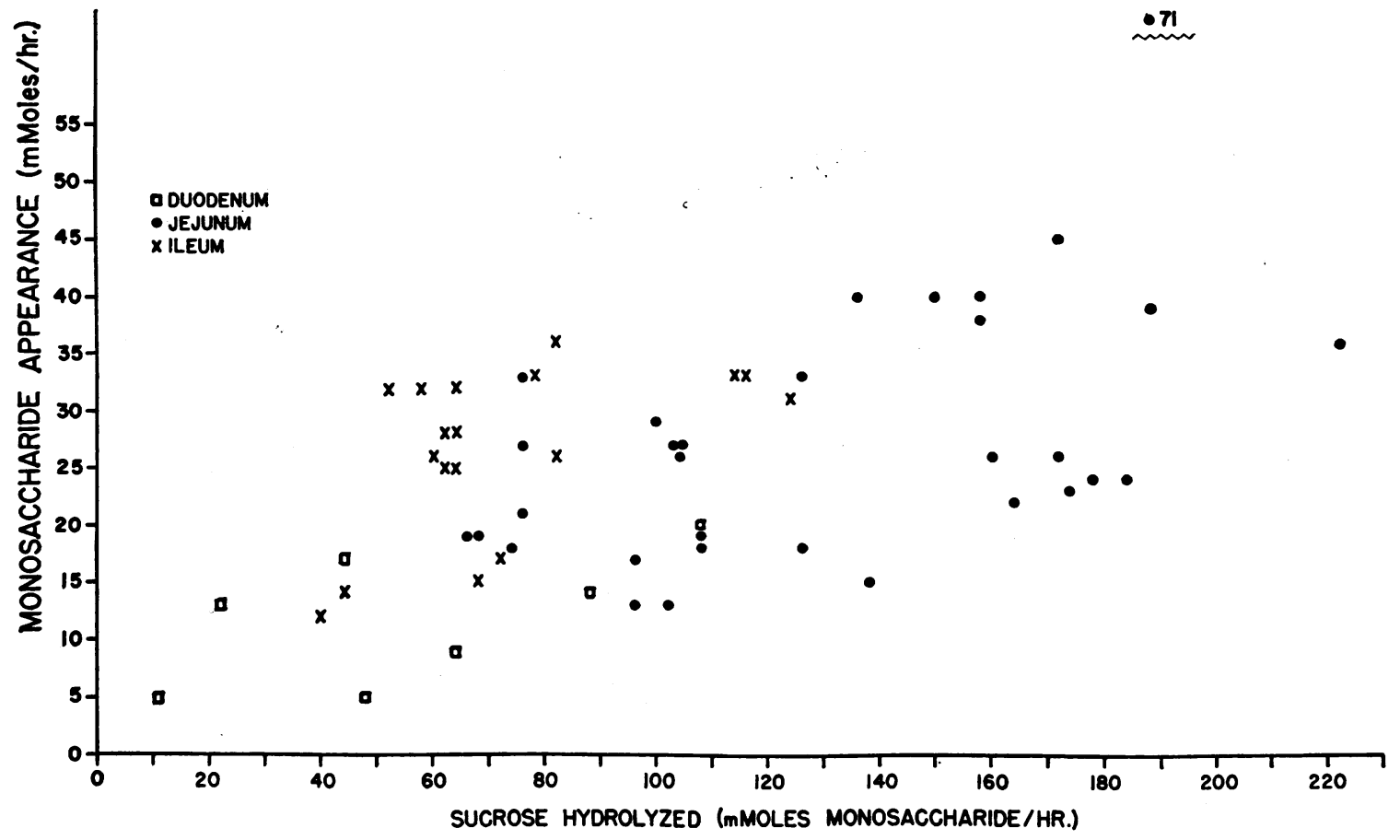

Fig. 4. Intraluminal monosaccharide APPEARANCE DURING SUCRose ABSORPTion. There is a low order of linear correlation $(r=0.51)$ between amounts of monosaccharides that appeared and of sucrose that was hydrolyzed.

chromatography by the method of Bickel (20-21) of the intestinal contents from the subjects given the meal verified the presence of glucose and fructose.

\section{Discussion}

The infusion studies demonstrated efficient hydrolysis and absorption of sucrose in human jejunum at rates that were approximately twice as rapid as in ileal segments. The extent of jejunal absorption can be appreciated from Figure 2, which shows that an average of $50 \%$ of the sucrose infused was absorbed; this amounts to 22 g per hour per $30-\mathrm{cm}$ segment.

The meal studies showed almost complete absorption of the ingested sucrose in jejunum, which is in contrast to the minimal absorption (about $15 \%)$ previously reported by Dahlqvist and Borgström (1). These markedly different results cannot be ascribed to techniques of sugar analysis

TABLE I

Summary of sucrose infusion studies*

\begin{tabular}{|c|c|c|c|c|c|c|c|}
\hline \multirow[b]{2}{*}{ Site } & \multirow[b]{2}{*}{$\begin{array}{l}\text { No. of } \\
\text { studies }\end{array}$} & \multirow[b]{2}{*}{$\begin{array}{l}\text { Infusion } \\
\text { concen- } \\
\text { tration }\end{array}$} & \multirow[b]{2}{*}{$\begin{array}{c}\text { Sucrose } \\
\text { hydrolysis } †\end{array}$} & \multirow[b]{2}{*}{$\begin{array}{c}\text { Sucrose } \\
\text { absorption } \dagger\end{array}$} & \multirow{2}{*}{$\begin{array}{c}\text { Mean } \\
\text { intralu- } \\
\text { minal } \\
\text { monosac- } \\
\text { charide } \\
\text { appearance }\end{array}$} & \multicolumn{2}{|c|}{$\begin{array}{l}\text { Fraction of hy- } \\
\text { drolyzed sucrose }\end{array}$} \\
\hline & & & & & & $\begin{array}{l}\text { Accumulated } \\
\text { intralu- } \\
\text { minally }\end{array}$ & Absorbed $\ddagger$ \\
\hline & & $m M$ & $\begin{array}{l}\text { mmoles mono- } \\
\text { saccharide/hr }\end{array}$ & $\begin{array}{l}\text { mmoles mono- } \\
\text { saccharide/hr }\end{array}$ & mmoles/hr & $\%$ & $\%$ \\
\hline $\begin{array}{l}\text { Jejunum } \\
\text { Ileum }\end{array}$ & $\begin{array}{l}18 \\
13\end{array}$ & $\begin{array}{l}146 \\
146\end{array}$ & $\begin{array}{r}158 \pm 30 \\
82 \pm 24\end{array}$ & $\begin{array}{r}128 \pm 26 \\
55 \pm 24\end{array}$ & $\begin{array}{l}30 \\
27\end{array}$ & $\begin{array}{l}19 \\
33\end{array}$ & $\begin{array}{l}81 \\
67\end{array}$ \\
\hline $\begin{array}{l}\text { Jejunum } \\
\text { Ileum }\end{array}$ & $\begin{array}{r}11 \\
8\end{array}$ & $\begin{array}{l}73 \\
73\end{array}$ & $\begin{array}{l}94 \pm 18 \\
60 \pm 14\end{array}$ & $\begin{array}{l}73 \pm 21 \\
37 \pm 8\end{array}$ & $\begin{array}{l}21 \\
23\end{array}$ & $\begin{array}{l}22 \\
38\end{array}$ & $\begin{array}{l}78 \\
62\end{array}$ \\
\hline
\end{tabular}

* Values for hydrolysis and absorption expressed as mean \pm SD.

$\dagger$ Jejunal studies show statistically significant greater values than ileal $(p<0.001)$.

$\ddagger$ Jejunal studies show statistically significant greater values than ileal $(p<0.01)$. 


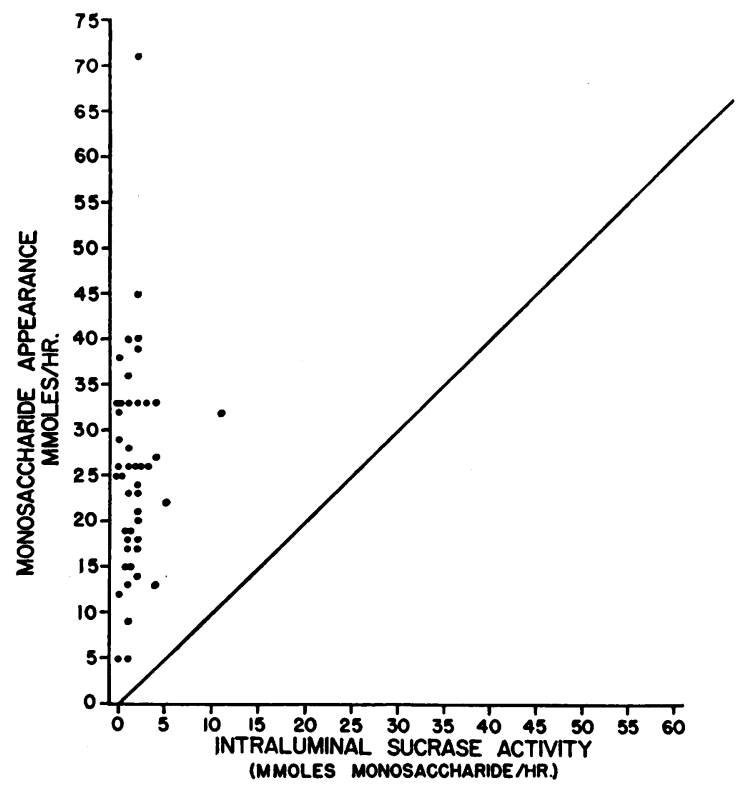

Fig. 5. Relationship of intraluminal sucrase aCTIVITY TO ACCUMULATION OF MONOSACCHARIDES (GLUCOSE PLUS FRUCTOSE) INTRALUMinally. Values above the diagonal line are too great to be accounted for by intraluminal sucrase activity.

since we found results by use of the dinitrosalicylic acid method (24) in these meal experiments to be within $10 \%$ of those determined by our enzymatic assay.

The present studies showing rapid hydrolysis and absorption of sucrose in upper and mid-jejunum are compatible with the extensive human disaccharidase assay experiments of Auricchio and co-workers (5) that demonstrated appreciable sucrase activity in jejunal mucosa obtained either by peroral biopsy or at surgery. Also supporting our findings are the data of a recent case report (2) of lactose intolerance in a patient who had a normal blood sugar rise after the ingestion of sucrose even though the ileum had been surgically removed 3 months previously. Thus it appears that the site of absorption of sucrose is no different from that of other disaccharides $(1,25)$ and monosaccharides (26-28).

It has previously been reported that intraluminal sucrase activity cannot account for the rate of disappearance of sucrose from the intestine $(1,8)$. In addition, our studies demonstrate that intraluminal sucrase activity also could not explain the rate of appearance of the monosaccharide hydroly-
TABLE II

Effect of incubation of intestinal contents on sucrase activity*

\begin{tabular}{cccc}
\hline \hline \multirow{2}{*}{$\begin{array}{c}\text { Subject } \\
\text { no. }\end{array}$} & \multicolumn{3}{c}{ Incubation timet before sucrase assay } \\
\cline { 2 - 4 } & $\begin{array}{c}\text { No incu- } \\
\text { bation }\end{array}$ & $1 \mathrm{hr}$ & $2 \mathrm{hr}$ \\
\hline 1 & 4.0 & 4.8 & 5.0 \\
2 & 1.9 & 1.5 & \\
3 & 3.6 & 3.4 & 3.2 \\
14 & 1.6 & 1.5 & 1.5 \\
15 & 27 & 24 & 22 \\
\hline
\end{tabular}

* Activity expressed as millimoles monosaccharide released per hour per liter intestinal contents.

$\dagger$ Incubation at $37^{\circ} \mathrm{C}$.

sis products in intestinal contents during the process of sucrose absorption. Apparently, therefore, the glucose and fructose that accumulated in intraluminal contents were released from sucrose hydrolyzed by mucosa-bound enzyme, and these monosaccharides then moved from the mucosal surface to the lumen to be absorbed in the perfused segment or at more distal intestinal levels. Sucrase has been shown to be localized at the luminal side of the epithelial cell in the brush border (29), and hence products released when sucrose is hydrolyzed might well have access to the lumen, especially if the absorbing mechanism for the released monosaccharides were saturated.

Since sucrase activity is no different in jejunal or ileal mucosa (5), the slower hydrolysis rates in ileum could possibly be explained by the fact that the surface area per unit length of intestine is considered to be less in ileum (30-32). However, a greater percentage of the released monosaccharide products was absorbed in jejunum than in

TABLE III

Sucrose-protein-fat meal*

\begin{tabular}{ccccc}
\hline \hline Subject & $\begin{array}{c}\text { Tube } \\
\text { position† }\end{array}$ & $\begin{array}{c}\text { \% sucrose } \\
\text { hydrol- } \\
\text { ysis }\end{array}$ & $\begin{array}{c}\text { \% sucrose } \\
\text { absorp- } \\
\text { tion }\end{array}$ & $\begin{array}{c}\text { accumu- } \\
\text { intralu- } \\
\text { minally } \\
\text { as mono- } \\
\text { saccharide }\end{array}$ \\
\hline & $c m$ & & & \\
S. W. & 130 & 99 & 93 & 6 \\
G. H. & 150 & 100 & 92 & 8 \\
J.S. & 150 & 100 & 100 & 0 \\
B. S. & 160 & 100 & 98 & 2
\end{tabular}

* The meal contained $54 \mathrm{~g}$ sucrose, $22 \mathrm{~g}$ corn oil, $21 \mathrm{~g}$ egg albumin, $1 \mathrm{egg}$ yolk, and $4 \mathrm{~g}$ polyethylene glycol.

$\dagger$ Tube position refers to distance from teeth to collecting orifice. 
ileum, indicating that absorption lags proportionately further behind hydrolysis in ileum than in jejunum. If surface area difference were the only important factor, a parallel decrease in both hydrolysis and absorption would have been expected at lower levels of intestine. Therefore some factor or factors other than mere surface area differences probably play a role in producing different absorption rates from jejunum and ileum.

Lack of proportional change in hydrolysis and absorption could have occurred if sucrose were hydrolyzed intraluminally in ileum by bacteria to a greater extent than in jejunum, thereby resulting in an artificially high ileal hydrolysis rate. However, neither aerobic nor anaerobic sucrase assay, which should measure bacterial as well as succus entericus enzyme activity, demonstrated the intraluminal activity that would be necessary to explain the proportionately greater accumulation of monosaccharides within the ileal lumen.

\section{Summary}

1) The site of intestinal absorption of the disaccharide sucrose was studied in normal man by the use of both an oral meal and an infusion technique. Contrary to current opinion, both hydrolysis and absorption were quite efficient in human jejunum. Furthermore, as demonstrated by the infusion experiments, sucrose absorption rates were considerably more rapid in jejunal segments than in ileal segments $(p<0.001)$.

2) In addition to the lower rates of hydrolysis and absorption in ileum, absorption appeared to be retarded even more than hydrolysis at ileal as compared to jejunal levels of intestine. This suggests that a difference in surface area cannot account by itself for the greater absorption rates in jejunum.

3) During sucrose absorption appreciable amounts of glucose and fructose appeared in the intestinal lumen. The amounts of the monosaccharide products of sucrose hydrolysis that accumulated could not be explained by intraluminal sucrase activity. These findings suggest that considerable amounts of glucose and fructose were released from sucrose hydrolyzed by mucosabound enzyme and that these monosaccharides moved from the mucosal surface to the lumen to be absorbed subsequently.

\section{Acknowledgments}

The authors are grateful to Dr. Robert K. Crane for many helpful suggestions, to Dr. Normand Fortier for generous advice on the use of the hexokinase system, and to Mrs. P. Taggart and Miss P. Murray for technical assistance.

\section{References}

1. Dahlqvist, A., and B. Borgström. Digestion and absorption of disaccharides in man. Biochem. J. 1961, 81, 411.

2. Kern, F., Jr., J. E. Struthers, Jr., and W. L. Attwood. Lactose intolerance as a cause of steatorrhea in an adult. Gastroenterology 1963, 45, 477.

3. Dahlquist, A., and D. L. Thomson. The digestion and absorption of sucrose by the intact rat. J. Physiol. (Lond.) 1963, 167, 193.

4. Dahlqvist, A. Specificity of the human intestinal disaccharidases and implications for hereditary disaccharide intolerance. J. clin. Invest. 1962, 41, 463.

5. Auricchio, S., A. Rubino, R. Tosi, G. Semenza, M. Landolt, H. Kistler, and A. Prader. Disaccharidase activities in human intestinal mucosa. Enzymol. biol. clin. (Basel) 1963, 3, 193.

6. Fordtran, J. S., K. H. Soergel, and F. J. Ingelfinger. Intestinal absorption of $\mathrm{D}$-xylose in man. New Engl. J. Med. 1962, 267, 274.

7. Hirsch, J., E. H. Ahrens, Jr., and D. H. Blankenhorn. Measurement of the human intestinal length in vivo and some causes of variation. Gastroenterology 1956, 31, 274.

8. Borgström, B., A. Dahlqvist, G. Lundh, and J. Sjövall. Studies of intestinal digestion and absorption in the human. J. clin. Invest. 1957, 36, 1521.

9. Hydén, S. A turbidometric method for the determination of higher polyethylene glycols in biologic materials. Ann. roy. Agr. Coll. Sweden 1955, 22, 139.

10. Somogyi, M. Determination of blood sugar. J. biol. Chem. 1945, 160, 69.

11. Huggett, A. St. G., and D. A. Nixon. Use of glucose oxidase, peroxidase, and o-dianisidine in determination of blood and urinary glucose. Lancet 1957, 2, 368.

12. Dahlqvist, A. Determination of maltase and isomaltase activities with a glucose-oxidase reagent. Biochem. J. 1961, 80, 547.

13. Blecher, M., and A. B. Glassman. Determination of glucose in the presence of sucrose using glucose oxidase; effect of $\mathrm{pH}$ on absorption spectrum of oxidized o-dianisidine. Analyt. Biochem. 1962, 3, 343.

14. Schmidt, F. H. Die enzymatische Bestimmung von Glucose und Fructose nebeneinander. Klin. Wschr. 1961, 39, 1244. 
15. Beisenherz, G., T. Bücher, and K. Garbade. $\gamma$ Glycerophosphate dehydrogenase from rabbit muscle in Methods in Enzymology, S. P. Colowick and N. O. Kaplan, Eds. New York, Academic Press, 1955, vol. 1, p. 392.

16. Bernard, C. Du suc gastrique et de son rôle dans la nutrition. Thesis, University of Paris, 1843, vol. 398 , no. 242.

17. Keith, N. M., and M. H. Power. The urinary excretion of sucrose and its distribution in the blood after intravenous injection into normal men. Amer. J. Physiol. 1937, 120, 203.

18. Dean, N., and H. W. Smith. Fate of inulin and sucrose in normal subjects as determined by a urine reinfusion technique. J. clin. Invest. 1955, 34, 681 .

19. Peterson, R. E., J. J. O’Toole, W. M. Kirkendall, and O. Kempthrone. The variability of extracellular fluid space (sucrose) in man during a 24-hour period. J. clin. Invest. 1959, 38, 1644.

20. Bickel, H. Mellituria, a paper chromatographic study. J. Pediat. 1961, 59, 641.

21. Bickel, H. Zur klinischen Bedeutung verschiedener Melliturien. Mod. Probl. Pädiat. 1959, 4, 136.

22. Darling, S., O. Mortensen, and G. Søndergaard. Lactosuria and amino-aciduria in infancy. A new inborn error of metabolism. Acta paediat. (Uppsala) 1960, 49, 281.

23. Gryboski, J. D., W. R. Thayer, Jr., W. A. Gryboski, I. W. Gabrielson, and H. M. Spiro. A defect in disaccharide metabolism after gastrojejunostomy. New Engl. J. Med. 1963, 268, 78.
24. Hostettler, F., E. Borel, and H. Deuel. Über die Reduktion der 3,5-dinitrosalicylsäure durch Zucker. Helv. chim. Acta 1951, 34, 2132.

25. Gray, G. M., and F. J. Ingelfinger. Unpublished observations.

26. Groen, J. The absorption of hexoses from the upper part of the small intestine in man. J. clin. Invest. 1937, 16, 245.

27. Schedl, H. P., and J. A. Clifton. Kinetics of intestinal absorption in man: normal subjects and patients with sprue (abstract). J. clin. Invest. 1961, 40, 1079.

28. Fordtran, J. S., P. H. Clodi, K. H. Soergel, and F. J. Ingelfinger. Sugar absorption tests, with special reference to 3-0-methyl-d-glucose and d-xylose. Ann. intern. Med. 1962, 57, 883.

29. Miller, D., and R. K. Crane. The digestive function of the epithelium of the small intestine. II. Localization of disaccharide hydrolysis in the isolated brush border portion of intestinal epithelial cells. Biochim. biophys. Acta (Amst.) 1961, 52, 293.

30. Verzár, F., and E. J. McDougall. Absorption from the intestine. London, Longmans, Green, 1936, p. 9.

31. Wood, H. O. The surface area of the intestinal mucosa in the rat and in the cat. J. Anat. (Lond.) 1944, 78, 103.

32. Fisher, R. B., and D. S. Parsons. The gradient of mucosal surface area in the small intestine of the rat. J. Anat. (Lond.) 1950, 84, 272. 